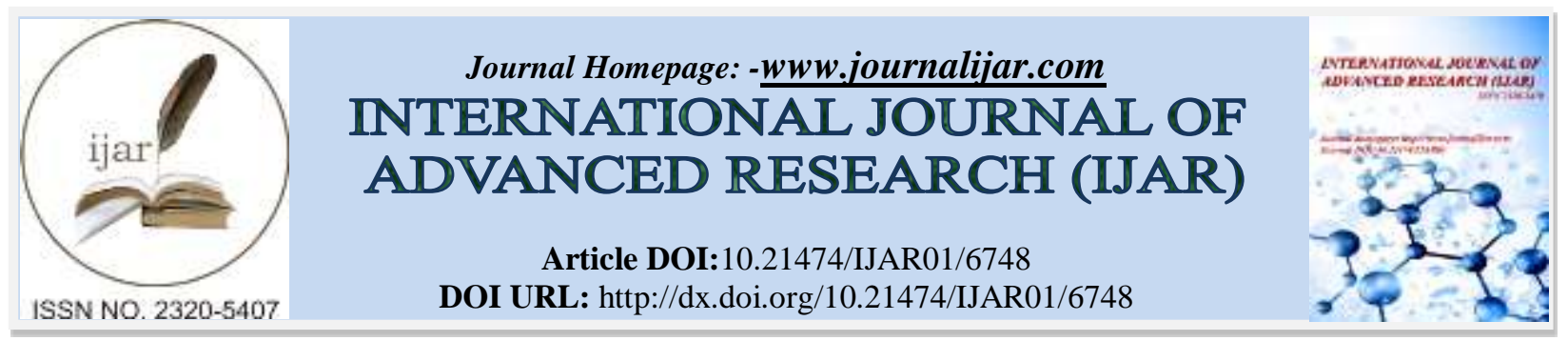

RESEARCH ARTICLE

\title{
MOLECULAR IDENTIFICATION OF STREPTOMYCES PHAEOPURPUREUS ISOLATED FROM MARINE SEDIMENTS, VISAKHAPATNAM, USING 16S RRNA GENE SEQUENCE ANALYSIS.
}

Sari Dharmaveera, Sandhya Deepika D and Yamuna M M.

Department of Botany, Andhra University, Visakhapatnam, India. Pin- 530003.

\section{Manuscript Info}

Manuscript History

Received: 15 January 2018

Final Accepted: 17 February 2018

Published: March 2018

Keywords:-

Streptomyces phaeopurpureus, $16 \mathrm{~s}$ rRNA gene sequence, neighbour-joining algorithm and phylogenetic analysis.

\begin{abstract}
In order to obtain different actinomycetes isolates from the Visakhapatnam marine soils, an isolation study was carried out by using different growth media. A molecular taxonomic method, 16S rDNA gene sequencing, was applied to obtain high virulent isolate (DHB-603) isolated from Visakhapatnam marine soils. Phylogenetic dendrograms based on 16S rDNA nucleotide sequences were constructed by using neighbour-joining algorithm and maximum likelihood methods. In the light of phylogenetic analyses, it was determined that DHB-603 showed 99.5\% similarity with Streptomyces phaeopurpureus, and in phylogenetic tree also DHB-603 and Streptomyces phaeopurpureus were in the same branch. Soil isolate obtained from this study contribute to taxonomy of Streptomyces and also many species will emerge.
\end{abstract}

Copy Right, IJAR, 2018,. All rights reserved.

\section{Introduction:-}

Streptomyces species are abundant micro-organisms in soil and are well known for their ability to produce biologically active secondary metabolites, particularly antibiotics. Interestingly, only a small number of Streptomyces species are known to be plant or animal pathogens (Loria et al., 1997). Members of the genus Streptomyces are filamentous Gram positive soil bacteria with a typical base composition of $72-75 \mathrm{~mol} \% \mathrm{G}+\mathrm{C}$ (Enquist \& Bradley, 1971 ; Piepersberg, 1993). Streptomycetes undergo complex morphological differentiation including growth of substrate mycelia in the initial phase, followed by development of aerial mycelium and its subsequent conversion to spores (Piepersberg, 1993).

Streptomycetes possess extensive secondary metabolic pathways leading to the production of a wide array of bioactive compounds including many commercially important substances such as antibiotics. The metabolic diversity of these indigenous soil micro-organisms has been widely exploited in industry and agriculture. Selective methods for detecting and identifying these micro-organisms are needed in order to gain insights into the population and genome dynamics of Streptomyes in natural environments, in particular the distribution of unstable genetic material such as the biosynthesis genes for antibiotic production (Piepersberg, 1993 ; Phillips \& Wellington, 1992).

Some organisms that are in advertently placed in an ineligible group are now classified appropriate owing to the advent of molecular techniques (Zhi et al., 2009). Recently, the identification of the species and phylogenies are commonly derived from 16S rDNA and the use of polymerase chain reaction (PCR) for sequence analyses (Wood et al., 2007; Zhi et al., 2009). Majority of actinomycetes are commonly found in both aquatic and terrestrial habitats 
(Macagnan et al., 2006). The best known actinomycetes in soil is the genus Streptomyces although others, like Norcardia, Microbispora, Micromonospora, Actinomyces, Actinoplanes and Streptosporangium, have also been isolated from soil. The number and variety of actinomycetes present in any soil sample would be significantly influenced by geographical location, soil temperature; type and $\mathrm{pH}$, organic matter content, agri-cultural activities, aeration, nutrient availability, moisture content and soil vegetation (Arifuzzaman et al., 2010). Presently, different antimicrobial compounds likely to be obtained are decreasing day by day from action-mycete groups. Nowadays, obtaining new antibiotics from rare actinomycetes is industrially important (Hayakawa, 2008).

16S rRNA gene sequencing is a powerful method for elucidating phylogenetic relationships among prokaryotic organisms (Woese, 1987; Stackebrandt et al., 1997) and has been used to facilitate the differential identification of the genus Streptomyces (Mehling et al., 1995; Kreuze et al., 1999). Nevertheless, 16S rRNA gene sequences may be insufficient to define phylogenetic relationships among closely related species and among strains belonging to a species because of the evolutionary conservation of 16S rRNA (Woese, 1987). In comparison with 16S rRNA gene sequences, sequences of 16S-23S rDNA internally transcribed spacer (ITS) regions are more variable and have been shown to be useful in inferring the phylogenetic relationships between closely related organisms (Gürtler \& Stanisich, 1996). Recently, the number, size and sequences of 16S-23S ITS regions were used for discrimination of Streptomyces albidoflavus strains (Hain et al., 1997), genetic analysis of the genus Nocardioides (Yoon et al., 1998) and clarification of the relationship between members of the family Thermomonosporaceae (Zhang et al., 2001).

In the present study, we determined 16S rRNA gene sequences to classify high antibiotic producing strain of Streptomyces isolates from marine sediment of Visakhapatnam coast by using the neighbour joining and maximum likelihood methods.

\section{Materials and methods:-}

\section{Collection and isolation of Marine Sediment Samples:-}

A marine sediment samples were collected from Visakhapatnam coast, India. These Actinobacteria were isolated from marine sediment samples by plating them on suitable agar media with different dilutions. Actinobacteria colonies can easily be distinguished on the plate from those of fungi and non-filamentous bacteria.

\section{Morphological Characteristics:-}

For the selected high active isolate DHB-603, macro, micro morphological features of colony, colour characteristics of the aerial mycelium, substrate mycelium, soluble pigments and biochemical characters were evaluated after 14 days of incubation at $28^{\circ} \mathrm{C}$.

\section{Molecular characterization:- \\ Bacterial strains and culture conditions:-}

The strain used in this study were grown in shaking flasks containing GYM (Streptomyces medium; DSM Z Medium 65) at $28^{\circ} \mathrm{C}$.

\section{Isolation of chromosomal DNA:-}

Chromosomal DNAs were isolated by a versatile quick-prep method for genomic DNA of Gram-positive bacteria (Pospiech \& Neumann, 1995), with some modifications. Mycelia (1-2 ml) grown in a GYM broth shake culture were centrifuged, rinsed with TE and resuspended in $0.4 \mathrm{ml}$ SET buffer $(75 \mathrm{mM} \mathrm{NaCl}, 25 \mathrm{mM}$ EDTA, $20 \mathrm{mM}$ Tris, $\mathrm{pH}$ 7.5). Lysozyme was added to a concentration of $1 \mathrm{mg} / \mathrm{ml}$ and incubated at $37^{\circ} \mathrm{C}$ for $30 \mathrm{~min}-1 \mathrm{~h}$. Then $0.1 \mathrm{vols}$ $10 \% \mathrm{SDS}$ and $0.5 \mathrm{mg}$ Proteinase $\mathrm{K} \mathrm{ml}^{-1}$ were added and incubated at $55^{\circ} \mathrm{C}$ with occasional inversion for $2 \mathrm{~h}$. Onethird volume $5 \mathrm{M} \mathrm{NaCl}$ and 1 vol. chloroform were added and incubated at room temperature for 30 min with frequent inversion. The mixture was centrifuged at $4500 \mathrm{~g}$ for $15 \mathrm{~min}$ and the aqueous phase was transferred to a new tube using a blunt-ended pipette tip. Chromosomal DNA was precipitated by the addition of 1 vol. 2-propanol with gentle inversion. The DNA was transferred to a new tube, rinsed with $70 \%$ ethanol, dried under vacuum and dissolved in a suitable volume (about $100 \mathrm{ml}$ ) of distilled water. The dissolved DNA was treated with $20 \mathrm{mg}$ RNase$\mathrm{A} \mathrm{m}^{-1}$ at $37^{\circ} \mathrm{C}$ for $1 \mathrm{~h}$. Samples were extracted in the same volume of phenol/chloroform/isoamyl alcohol (25: $24:$ 1) and precipitated with 2.5 vols cold ethanol and 0.1 vols $3 \mathrm{M}$ sodium acetate. The pellets were washed with $70 \%$ ethanol, dried and dissolved in TE or distilled water. 


\section{S rRNA gene sequence analysis:-}

With the above isolated genomic DNA, two universal primers 27F (5'AGAGTTTGATCMTGGCTCAG 3') and 5' TACGGYTACCTTGTTACGACTT 3' were used to amplify $16 \mathrm{~S}$ rRNA genes. PCR reaction mixture of $25 \mu 1$ total volume, containing $1 / 10$ volume $10 \times$ Taqbuffer, $2 \mathrm{~mm} \mathrm{MgCl}_{2}, 1$ unit TaqDNA polymerase, $0.2 \mathrm{mMdNTP}, 20$ pmolforward primer, 20 pmolreverse primer and $100 \mathrm{ng}$ DNA. DNA amplification was carried out in a Biorad Mini thermocycler with the following procedure: an initial denaturing step at $94^{\circ} \mathrm{C}$ for $5 \mathrm{~min}$; 40 cycles for 1 min at $94^{\circ} \mathrm{C}$ (denature), $1 \mathrm{~min}$ at $48^{\circ} \mathrm{C}$ (annealing), $2 \mathrm{~min}$ at $72^{\circ} \mathrm{C}$ (extension) and a final elongation step at $72^{\circ} \mathrm{C}$ for $5 \mathrm{~min}$. PCR products were separated by electrophoresis on $1.5 \%$ agarose gel containing $0.5 \mu \mathrm{g} / \mathrm{ml}$ ethidium bromide, and photographed. The standard DNA samples (100 bp DNA ladder marker) were used as molecular size marker. The purified PCR products was subjected to Sanger's di-deoxy sequencing, in both forward and reverse directions, using BigDye terminator v3.1 cycle sequencing kit on ABI Prism3700 DNA Analyzer (Applied Biosystems Inc., USA) as per manufacturer's instructions.

The resulting 16S rDNA gene sequences (1.325-1.435 nucleotides) were used to search the GenBank/EMBL/DDBJ database with the BLAST program (http://www.ncbi.nlm.nih.gov/) to determine relative phylogenetic positions. Phylogenetic analysis was conducted using MEGA 6.0 (Tamura et al., 2011) by first generating a complete alignment of $16 \mathrm{~S}$ rDNA gene sequences of the isolates and type strains of all valid species. A phylogenetic tree was inferred using neighbour-joining tree algorithms (Jukes and Cantor, 1969). 16S rDNA datasets were cooperatively analysed using MEGA 6.0 (Tamura et al., 2011) which was used to calculate evolutionary distances and similarity values. Topography of the constructed tree was evaluated by bootstrap analysis with 1000 replicates (Saitou and Nei, 1987). Only nodes with bootstrap values over $50 \%$ were considered to be significant.

\section{Phylogenetic analysis:-}

Multiple sequence alignment by CLUSTAL W 1.8 (Thompson et al., 1994). The resultant sequence alignment can then be used for the neighbour-joining (Saitou and Nei, 1987), maximum-parsimony (Fitch, 1971) and maximumlikelihood (Felsenstein, 1981) methods using the MEGA 6.0 (Tamura et al., 2011) package; all were implemented within the server. The alignment can be exported for use by external programs including MEGA 6.0 (Tamura et al., 2011) and BioEdit (version 7.2.0, Hall, 1999). An evolutionary distance matrix was generated for the neighbourjoining as described by Jukes and Cantor (1969). The resultant tree topology was evaluated by a bootstrap analysis (Felsenstein, 1985) with 1000 resamplings from the neighbour-joining dataset using Seqboot and Consense from the Phylip package (Felsenstein, 1993).

\section{Result and discussion:-}

Studies were performed using several selective isolation techniques in order to assess the diversity of actinomycetes in different natural habitats (Goodfellow and Fiedler, 2010). In this study, various selective media have also been used for actinomycete isolation from plateau soil samples. Totally one hundred and one strain were isolated on humic acid-vitamin (HV), tryptone-yeast glucose extract (TYG) and glucose-yeast extract (GYEA) agars supplemented with nalidixic acid, rifampicin and cycloheximide (Yamamura et al., 2003).

In the present study the isolated high active isolate DHB-603 was grey in colour, colonies were spiral shaped, vegetative mycelium was brown colour and it produce brown colour pigments. Isolates putatively assigned to the rare Streptomyces on the basis of colony morphology-notably spore mass colour, substrate mycelial pigmentation and the colour of diffusible pigment were subcultured on oatmeal agar (Küster, 1959) and tryptone-yeast glucose extract agar (Blackall et al., 1989). Indication of different pigmentation of fifteen rare actinomycetes colonies were selected to study further molecular techniques. All of the strains were main-tained on glucose-yeast extract agar (GYEA; Gordon and Mihm, 1962).

The 16S ribosomal RNA gene was amplified by using the PCR method with Taq DNA polymerase and primers $27 \mathrm{f}$ and 1492r. The molecular-based methods using polymerase chain reaction (PCR) is suitable for taxonomic studies. Samples of PCR product patterns of some representatives of test strains are given in Figure 1. During the analysis based on 16S rDNA gene se-quencing 800R, MG3f, MG5f, 1115r and 1492r primers were also used to get a nearly complete $16 \mathrm{~S}$ rDNA sequence data of test strain. 


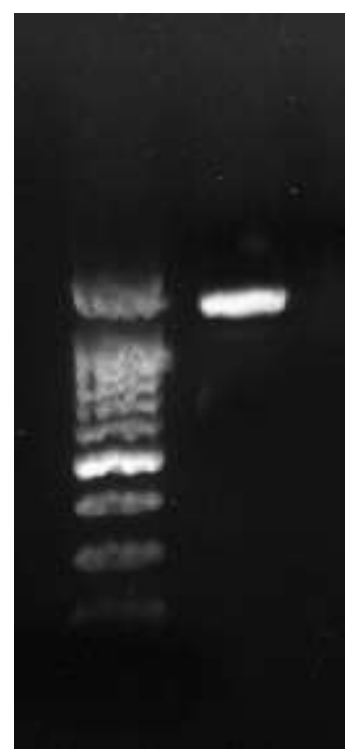

Figure 1:- Agarose gel showing 1490 bp 16s r RNA gene amplified product

16S rDNA gene sequence data was determined for the twelve test strains according to Blast analysis and a 1438 nucleotide base pair was used for phylogenetic analysis and compared with 16S rDNA gene sequences of tree representatives of closely related type strains of Streptomyces (Figure 2). Isolate DHB-603 showed 99.5\% similarity with Streptomyces phaeopurpureus, and in phylogenetic tree also DHB-603 and Streptomyces phaeopurpureus were in the same branch.

\section{Evolutionary relationships of taxa:-}

The evolutionary history was inferred using the UPGMA method. The optimal tree with the sum of branch length $=0.02515357$ is shown. The tree is drawn to scale, with branch lengths in the same units as those of the evolutionary distances used to infer the phylogenetic tree. The evolutionary distances were computed using the Maximum Composite Likelihood method and are in the units of the number of base substitutions per site. The analysis involved 13 nucleotide sequences. All positions containing gaps and missing data were eliminated. There were a total of 1438 positions in the final dataset. Evolutionary analyses were conducted in MEGA7 (Figure 1). 


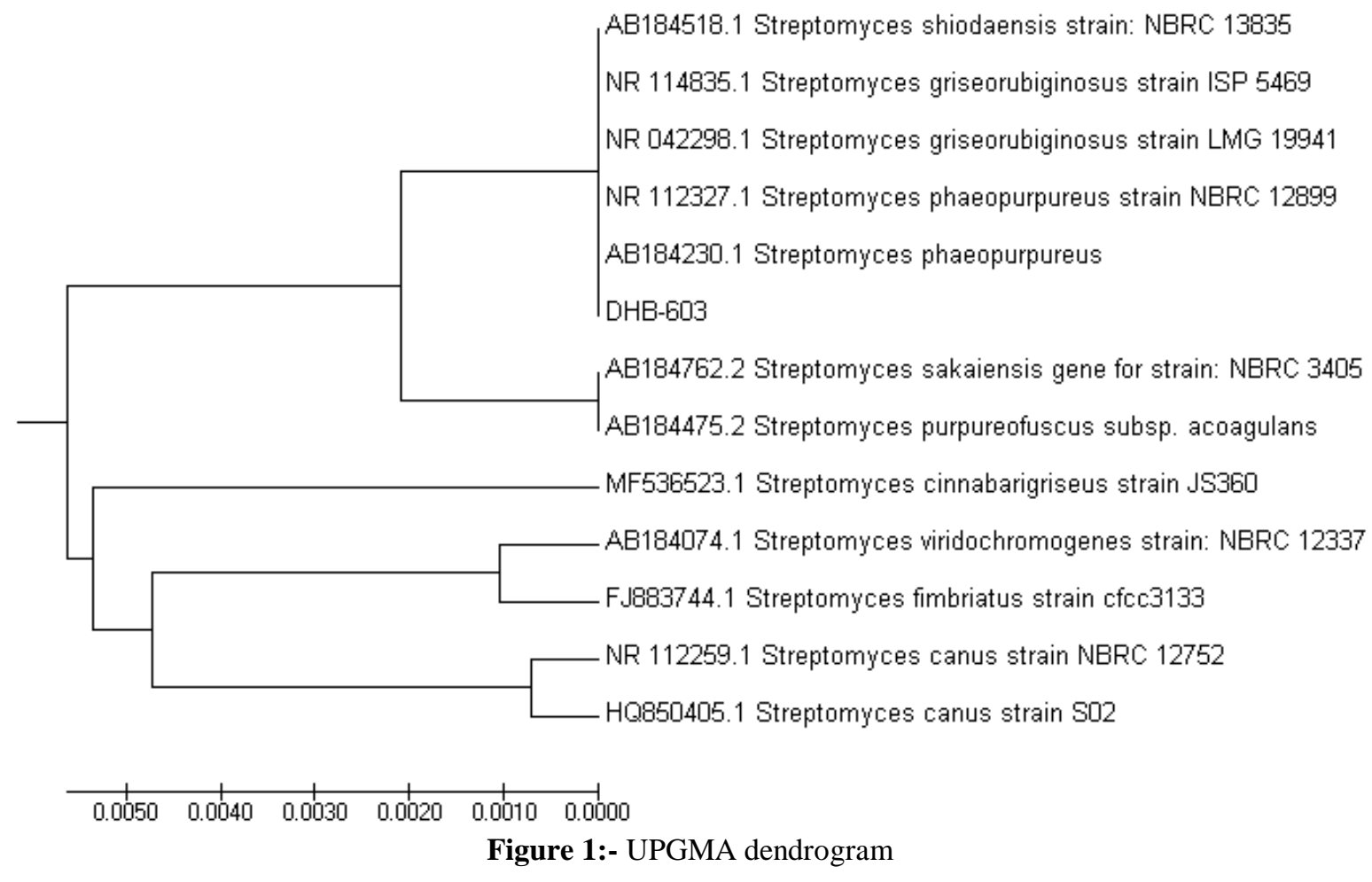

\section{Molecular Phylogenetic analysis by Maximum Likelihood method:-}

The evolutionary history was inferred by using the Maximum Likelihood method based on the Tamura-Nei model. The tree with the highest log likelihood (-2258.08) is shown. Initial tree(s) for the heuristic search were obtained automatically by applying Neighbor-Join and BioNJ algorithms to a matrix of pairwise distances estimated using the Maximum Composite Likelihood (MCL) approach, and then selecting the topology with superior log likelihood value. The tree is drawn to scale, with branch lengths measured in the number of substitutions per site. The analysis involved 13 nucleotide sequences. All positions containing gaps and missing data were eliminated. There were a total of 1438 positions in the final dataset. Evolutionary analyses were conducted in MEGA7 (Figure 2).

\section{Maximum Parsimony analysis of taxa:-}

The evolutionary history was inferred using the Maximum Parsimony method. Tree \#1 out of 10 most parsimonious trees (length $=39$ ) is shown. The consistency index is $0.897436(0.862069)$, the retention index is 0.931034 (0.931034), and the composite index is 0.835544 (0.802616) for all sites and parsimony-informative sites (in parentheses). The MP tree was obtained using the Subtree-Pruning-Regrafting (SPR) algorithm with search level 0 in which the initial trees were obtained by the random addition of sequences (10 replicates). The analysis involved 13 nucleotide sequences. All positions containing gaps and missing data were eliminated. There were a total of 1438 positions in the final dataset. Evolutionary analyses were conducted in MEGA7 (figure 2) 


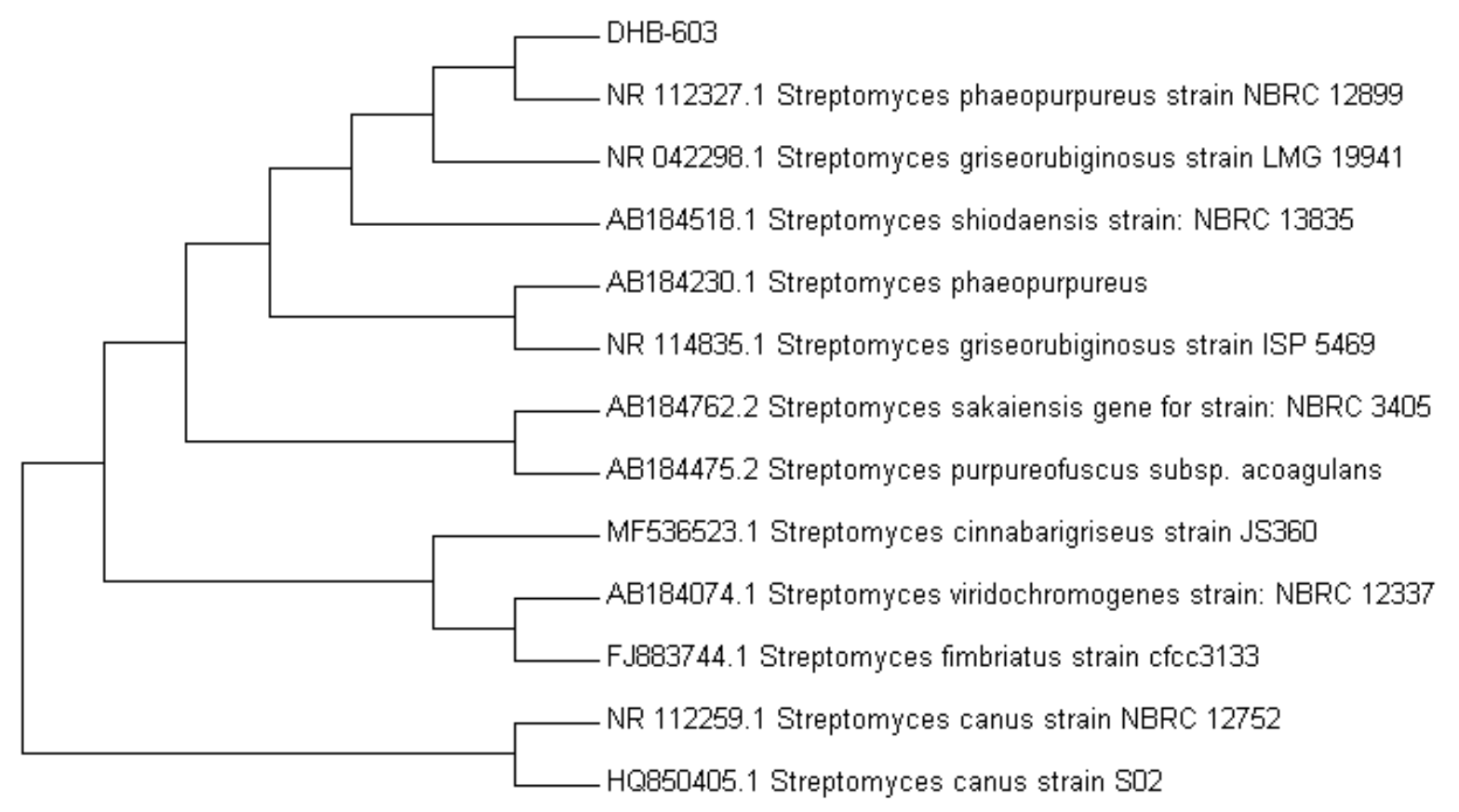

Figure 2:- Maximum Likelihood Dendrogram

\section{References:-}

1. Arifuzzaman M, Khatun MR, Rahman H (2010). Isolation and screening of actinomycetes from Sundarbans soil for antibacterial activity. Afr. J. Biotechnol. 9:4615-4619.

2. Blackall L, Parlett JH, Hayward AC, Minnikin DE, Greenfield PF, Harbers AE (1989). Nocardia pinensis sp. nov., an actinomycete found in activated sludge foams in Australia. J. Gen. Microbiol. 135:1547-1558.

3. Enquist LW, \& Bradley SG (1971). Characterization of deoxyribonucleotide acid from Streptomyces venepuelae species. Dev Ind Microbioll2, 225-236.

4. Felsenstein J (1981). Evolutionary trees from DNA sequences: a maximum likelihood approach. J. Mol. Evol. 17:368-376.

5. Felsenstein J (1985). Confidence limits on phylogeny:an appropriate use of the bootstrap. Evolution 39:783791.

6. Felsenstein J (1993). PHYLIP (Phylogeny inference package) version 3.5.1 (http://evolution.genetics.washington.edu/phylip.html).

7. Fitch WM (1971). Toward defining the course of evolution: minimum change for a specific tree topology. Syst. Zool. 20:406-416.

8. Goodfellow M, Fiedler HP (2010). A guide to succesful bioprospecting: informed by actinobacterial systematics. A. van. Leeuw. J. Microb. 98:119-142.

9. Gordon RE, Mihm JM (1962). Identification of Nocardia caviae comb. nov. Ann. NY. Acad. Sci. 98:628-639.

10. Gu“ rtler, V. \& Stanisich, V. A. (1996). New approaches to typing and identification of bacteria using the $16 \mathrm{~S}-$ 23S rDNA spacer region. Microbiology 142, 3-16.

11. Hain, T., Ward-Rainey, N., Kroppenstedt, R. M., Stackebrandt, E. \& Rainey, F. A. (1997). Discrimination of Streptomyces albidoflavus strains based on the size and number of 16S-23S ribosomal DNA intergenic spacers. Int J Syst Bacteriol 47, 202-206

12. Hall TA (1999). BioEdit: A user-friendly biological sequence alignment editor and analysis. http.//www.mbio.ncsu.edu/BioEdit/bioedit.html.

13. Hayakawa M (2008). Studies on the isolation and distribution of rare actinomycetes in soil. Actinomycetologica 22:12-19.

14. Jukes TH, Cantor CR (1969). Evolution of protein molecules. In Munro H.N (ed.) Mammalian protein metabolism, Acedemic Press, New York. pp. 21-132.

15. Jukes TH, Cantor CR (1969). Evolution of protein molecules. In Munro H.N (ed.) Mammalian protein metabolism, Acedemic Press, New York. pp. 21-132. 
16. Kreuze JF, Suomalainen S, Paulin L. \& Valkonen, J. P. T. (1999). Phylogenetic analysis of 16S rRNA genes and PCR analysis of the nec1 gene from Streptomyces spp. causing common scab, pitted scab, and netted scab in Finland. Phytopathology 89, 462-469.

17. Küster E (1959). Outline of a comparative study of criteria used in characterisation of the actinomycetes. Int. B. Bact. Nomencl. T. 9:97- 104.

18. Loria R, Bukhalid RA, Fry BA \& King RR. (1997). Plant pathogenicity in the genus Streptomyces. Plant Dis 81, 836-846.

19. Macagnan D, Romeiro R, de Souza J, Pomella A (2006). Isolation of actinomycetes and endospore-forming bacteria from the cacao pod surface and their antagonistic activity against the witches' broom and black pod pathogens. Phytoparasitica 34:122-132.

20. Mehling A, Wehmeier UF. \& Piepersberg, W. (1995). Application of random amplified polymorphic DNA (RAPD) assays in identifying conserved regions of actinomycete genomes. FEMS Microbiol Lett 128, $119-126$.

21. Phillips L. \&Wellington EM H. (1992). The distribution of DNA sequences hybridizing with antibiotic production and resistance gene probes within type strains and wild isolates of Streptomyces species. J Antibiot 45, 1481-1491.

22. Piepenberg W (1993). Streptomyces and Coynebacteria. In Biotechnology, pp. 434-468. Edited by H. J. Rehm \& G. Reed in cooperation with A. Piihler \& P. Stadler. Weinheim: VCH.

23. Pospiech A, Neumann B. (1995). A versatile quick-prep of genomic DNA from gram-positive bacteria. Trends Genet. 11(6):217-8.

24. Saitou N, Nei M (1987). The neighbour-joining method: a new method for reconstructing phylogenetic trees. Mol. Biol. Evol. 4:406-425.

25. Stackebrandt E, Rainey FA, Ward-Rainey NL (1997). Proposal for a new hierarchic classification system, Actinobacteria class nov. Int. J. Syst. Bacteriol. 47:479-491.

26. Tamura K, Peterson D, Peterson N, Stecher G, Nei M, Kumar S (2011). MEGA5: Molecular Evolutionary Genetics Analysis Using Maximum Likelihood, Evolutionary Distance and Maximum Parsinomy Methods. Mol. Bio. Evol. 28:2731-2739.

27. Thompson JD, Higgins DG, Gibson TJ (1994). CLUSTAL W: improving the sensitivity of progressive multiple sequence alignment through sequence weighting, position-specific gap penalties and weight matrix choice. Nucleic Acids Res. 22:4673-4680.

28. Woese CR. (1987). Bacterial evolution. Microbiol Rev 51,221-271.

29. Wood SA, Kirby BM, Goodwin CM, Le Roes M, Meyers PR (2007). PCR screening reveals unexpected antibiotic biosynthetic potential in Amycolatopsis sp. strain UM16. J. Appl. Microbiol. 102:245-253.

30. Yamamura H, Hayakawa M, Limura Y (2003). Application of sucrose-gradient centrifugation for selective isolation of Nocardia sp. from soil. J. App. Microbiol. 95:677-685.

31. Yoon HJ, Lee ST. \& Park, Y. H. (1998). Genetic analyses of the genus Nocardioides and related taxa based on 16S-23S rDNA internally transcribed spacer sequences. Int J Syst Bacteriol 48, 641-650.

32. Zhang Z, Wang Y, Ruan J (1998). Reclassification of Thermomonospora and Microtetraspora. Int. J. Syst. Bacteriol. 48:411-422.

33. Zhi XY, Li WJ, Stackebrand E (2009). An update of the structure and 16S rRNA gene sequence-based definition of higher ranks of the class Actinobacteria, with the proposal of two new suborders and four new families and emended descriptions of the existing higher taxa. Int. J. Syst. Evol. Microbiol. 59:589-608. 